\title{
2. HOW UNIVERSITIES HAVE BEEN POSITIONED AS TEAMS IN A KNOWLEDGE ECONOMY WORLD CUP
}

\author{
INIRODI CIION: IIIE IIICIIIR IIDUCAIION WORLDHAS BIIEN CIIANGID \\ Sombtimes an arem takes place that is twh momentous. Wo know that it is \\ irretersithe and that ater it haptens nothing will be quite the same again. \\ A tsmami sth w that which deverstated Aceh in Indomesia on 26 December \\ 20tht falls inte this category. So does a shaten and wheralded act of wat on \\ a large seate. strch as the attak on the American naval installation at Pearl \\ Hathen on Decomber 1941, w the howhing of the World Trade Cente and \\ the l'sulugen in the United States on 11 September 2001. Another such case \\ is the assussination of a charismatic political leakr who cannot be replaced. \\ so that history takes a different path. At the micto-level we expertionces the \\ same kiml of devastating change in the loss of a loved one, or collapse of \\ "t business that las ahsorbed all of on resonces and efforts. We can fall in \\ fore smdknly and profomdly; so that we have no choice hat to go with it. \\ Perlups the decpest of all these momentows, ireversible experiences is the \\ hivh of a child.
}

For those who work in higher education institutions around the world, the launch on the Internet of the first comprehensive set of global university rankings by the Shangha Jiao Tong University Institute of Higher Education in China (SJTUIHE) on 28 June 2003 was another one of these momentous events. Some grasped the significance of the Jiao Tong as soon as it appeared. Others became aware of it only as it began to reshape perceptions and behaviours ands the effects flowed back into their own nations and institutions. In that moment in June 2003 a credible world-wide hierarchy of research universities was created, in the form of the league tables that governed sporting competitions around the world. It was instantly understood and immediately seductive. It seemed that the arcane and archaic world of universities had been opened to everybody's scrutiny. The familiar spectacle of a league table of universities was readily translated into imaginings of a global university market. It locked into the world of cultural prestige and social status embodied in the leading institutions; it seemed to bring them to account, even to democratise them, as market consumption always does; and it was a potent technology for strategies and policies premised on the struggle for advantage.

The Jiao Tong ranking felt right. It fitted with what people knew. Harvard was on top followed by the three leading universities in California, Stanford, Caltech and Berkeley. Cambridge in the UK was next, then MIT and research universities

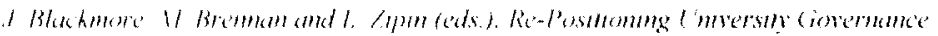

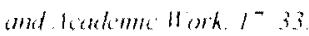

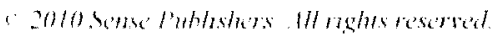


from the USA. UK and other nations ranging all the way down to number $500 \mathrm{in}$ the world. Everyone disavowed the exercise and pooh-poohed the measures and everyone wanted to know where their own university sat in the hierarchy and how close they were to greatness. It was irresistible.

Though lists of leading universities had appeared before. they were usually based on surveys of reputation. The results were of passing interest. a conglomeration of opinions that told people nothing about the fundamentals of relative pertormance or quality. The Jiao Tong was more compelling than its predecessors. It sprang from social science techniques that originated in census-style sociology and models of economic outputs rather than subjective market research. It measured the real activity of universities and in a manner that was comprehensible. There was a medium degree of complexity in the methodology of data processing leading to a single ordinal number for each university at the end. The Shanghat Jiao Tong University Institute also made several moves that grounded its "Academic Ranking of World Universities" effectively and in a lasting manner. It measured research performance in several ways. Many people immediately disputed the measures and their interpretation (and many still do) but it was difficult to dismiss all of the measures. The data were transparent and the sources were known: Nobel Prize winners, the identity of leading researchers by eitation. the number and quality of citations and publications (SJTUIHE, 2008).' The data sources could not be directly manipulated by the universities themselves or by national governments with a vested interest in 'their' university performance. The Shanghai Jiao l'ong team soon made it elear that they were willing to fine-tune the rankings on the basis of valid proposals for more accurate measures and they were utterly uninterested in special pleading, The Jiao Tong ranking withstood all attempts to discredit it and by 2005 it was thoroughly entrenched.

It was a remarkable achievement. A top ten university in China, an emerging rather than established system of research universities. relativised every university in the world including those located in the dominant country, the ISA. and so defined the global university market.

So the age of global university rankings was born and higher education was normalised as a single global competition of research universities, one system crossing every border: and as a quasi-market competition for status. for gifted and creative people and for resources on a worldwide scale. Half a decade later it is apparent that global research rankings are shaping and normalising worldwide higher education in much the same way that the annual rankings by the US News and World report have shaped American higher education since the 1920s. Since 2003 global rankings have fed into the accelerating 'arms race' in investments in innovation; and, in synchrony with the evolution of knowledge-intensive production. the globalisation of communications and the continuing advance of education. have helped to shift the idea of the 'global knowledge economy' from the edges of mainstream economic policy to the eentre of government thinking around the world. It seems that the global knowledge economy (and higher education and research along with it) have become the holy grail, the unrealisable essence at the heart of policy. A nation. or a meta-national region such as the EU. cannot have 
enough knowledge power. In a world of finite resources, knowledge is infinitely expanding and increasingly it is scen as the key to comparative advantage. It seems that the knowledge econony will guarantee the future and will meet all our needs. Growh. Wealth. Climate control. National success. Freedom, the brilliance of the human spirit, the triumph of the will. cte. University rankings give form to the idea of the global knowledge economy. especially the basic research aspect of it. They show governments and multinational business firms where knowledge power lies and lock universities firmly into the political economy.

Global university rankings have their critics and some have powerful and convincing arguments. After all it is preposterous to squeeze the vast diversity of higher education across the world. with its rich and remarkable range of approaches. systems, languages and creative products, into a single vertical table based on one vector of value which is North American style scientific research. It is like reducing the novels of Tolstoy to 30 -second sound bites or squeezing the libran of Alexandria into a toothpaste tube. No ranking system can satisfy everyone in its coverage (for a start. teaching performance is outside all of them at present) and the first Jiao Tong rankings have already spawned a diversity of mutations and metrics. There are few outright winners and many losers in a league table. On the face of $i t$, rankings ought to be wildly umpopular. But the rankings juggernaut rols on. For the foresecable future it is unstoppable because it meets the political, economic and cultural needs of the times. It provides substance for external pressures for accountability and performance and the rubrics of community and industry engagement. It feeds into the global student market. into the marketing pitch of institutions and the choice-making of prospective students. Pre-eminently global, it has the attraction of all one-stop "best in the world" summaries that, in our hubris. make the planet appear smaller and more controllable. Spectators at worldwide contests have power of a sort, at least to themselves. the power of opinion over what they see. The capacity to question the rankings is part of the charm they exert. And the thrill of winners and losers on this seale is popularly and deeply compelling. like the stories in history of the rise and fall of empires.

The pre-rankings era in higher education now appears as an age of pristine innocence. populated by beings of refined sensibilities that were oblivious to their looming fate. like the aesthetic cultures of the fin-de-siccle European cities before the onslaught of the first world war. The university ranking process is not fixed in stone. As Heraclitus said, everything is always becoming. University rankings will change in future and they will change aceording to conscious design: they may become greatly pluralised and the competitive edge of any particular league table might be blunted. But for good or ill global rankings are here to stay; and higher education and research - global. national and tocal - will never be the same again.

This chapter considers the origins. workings and policy effects of university rankings. It concludes with discussion of the junction between university rankings. university governance and systems of power at micro and macro levels, and it reflects on the global ordering of higher education that rankings entail. $A$ piece of scholarship of this length cannot do justice to what is already a vast subject in the national and global literatures but there are other summative accounts. surveys. 
reviews. evaluations and critiques available (Van Dyke. 2005: Usher \& Savino. 2006: Salmi \& Saroyan, 2006: Marginson \& van der Wende. 2007: 2009b: Hazelkon, 2008).

\section{Origins of Ciniversity Ramking}

In one sense, university ranking has no origin. Concentrations of knowledge power and status long pre-date modermity and are found at the beyinnings of urban cultures and incipient states. Most civilisations had their leading temples, churches and centres of learning. Philosophers' schools were vigorously set against each other in Athens and Rome. In another sense. present university ranking has several origins. Being still in its early stages at the global level, ranking continues to be the subject of heterogeneous invention and has yet to settle into predictable sy stems for managing human exchange in the manner of, say, transport or the financial sectors.

But a key precursor of the present development of global university ranking is the annual survey of American higher education by the US News and World Report. which dates back to the 1920s. Other origins lie in the Shanghai Jiao Tong Lniversity research ranking in 2003. which as noted has been decisive: the ranking of the "world's best universities" by the Times Higher Education Supplement from 2004 (The Times Higher, 2008): and the student-friendly comparisons of programs and services launched by the Centra for Higher Education Development and Die Zeit in Germany (CIIE. 2006). We are also seeing the mushrooming of systems of research metrics, for example Leiden University (CWTS, 2007), and the Higher Education Evaluation and Accreditation Council of Taiwan (2008). which revise the Jiao Tong approach in different ways: and the Webometries (2008) ranking of university presence on the web. The last group of developments will not be discussed here.

\section{US Ners and Wortd Repent}

The annual US News and World Report ranking began in the 1920s. It focuses principally on aspects of institutions seen to contribute to the quality of teaching and the student experience. thereby servicing the voucher style national student market which is underpinned by government-backed loans and university tuition scholarships. Research plays a minor role. There is not one ranking but seteral. sorted by institutional mission. using the classification system devised by the Carnegie Foundation for the Advancement of Teaching. The leading grouping is the 'National Universities', 248 universities ( 162 public and 86 private) with a range of fields of sudy, offering degrees to doctoral level and mostly research intensive (kirp. 2003, p. 12).

In the category of National Universities, 25 per cent of the index is comprised by a survey of "undergraduate academic excellence' sent to university presidents. provosts and deans of admissions. Two items each constitute 20 per cent: student retention and graduation rates: and "faculty resources" which rewards small classes. high academic salaries, high academic qualifications and a high proportion of staff full-time. Student selectivity at entry, a proxy for positional status, is 15 per cent. 
The lesser items are spending per student (10 per cent), the proportion of alumni who donate to the institution ( 5 per cent), and the graduation rate after controlling for spending and student aptitude (5 per cent). The US News ranking is managed b) a commercial publisher whose only motive is to sell magazines. Except for its annual goldmine. its special edition on "America's hest schools and colleges", US News is 'otherwise little-noticed' (Kirp, 2003, p. 25). Its categories and its statistical modelling are questioned. the combination of the elements into a single index number is un-theorised and arbitrary, and it is open to institutional lobbying and data manipulation. Nevertheless US News has captured the role of superintendent of higher education in the public interest. More than any other factor this much publicised amnal ranking has shaped the discourses and technologies (though not the political conomy, which has other foundations) of American higher education as a national market.

University Presidents can live and die on the basis of fluctuations in their US News position and over the years it has come to profoundly affect institutional helaviours. There is much at stake in the rankings exercise. "With each step upwards in the rankings. proportionately more of the students a college accepts, and more of those with high SAT scores. decide to enrol" (Kirp, 2003, p. 25). Universities and colleges have learned to modity themselves so as to maximise their US News position. Since the rate of alumni giving feeds into the US News rankings, some colleges climinate from their data base graduates they know will not donate. -Admissions ofticers cncourage as many students as possible to apply. knowing that the more applicants that a college rejects. the more selective it appears to be* (Kirp. 2003. p. 25-26). Some schools place their best applicants on a wait-list. knowing that they will not come anyway, and wanting to appear more selective. Institutions reduce the size of their initial intake so that refusal rates are ratcheted up and they can claim greater selectivity. letting in other students later as a supplementary cohort. More seriously, a growing proportion of student aid has been shifted from needs-based schemes designed to encourage students from social groups under-represented in higher education, to merit-based schemes targeting students with high SAT scores (Kirp, 2003, pp. 61-62). Thus rankings nominally designed for the public good have undermined it. There is a warning here. The US News experience suggests the possibility that the fostering of market subjectivities at the global level. via university ranking systems, has the potential to encourage behaviours that tundermine the global public good (Marginson, 2007a).

\section{The dian Tomg}

The Jiao Tong ranking was specifically created to service China s national policy. The conventional World Bank recipe for emerging nations is to build primary, secondary and tertiary education in that order. The government of China knew that in future it would need to make a transition from the medium technology manufacturing economy that was generating phenonenal rates of economic growth based on cheap labour from the countryside. to a knowledge-intensive services economy based on high educational levels. It opted for a radically different recipe 
to the conventional one. based on a more immediate transition to higher levels of skill without going through the World Bank's stages of economic development. It set itself the goal of immediately forming a modernised tertiary education system at OECD levels of participation. the rapid expansion of R\&D and the ereation of a system of world-class research universities.

Between 1990 and 2005 . tertiary student participation in China rose from 3 to 20 per cent of that age group (World Bank, 2008). Between 1998 and 2005, enrolled tertiary students multiplied by 4.5 times and the number of tertiary graduates multiplied by 3.7 times (Li. Whalley, Zhang \& Zhao, 2008, p. 5). Over the same time period quality has been lifted at all levels of tertiary education and there has been a remarkable growth in research activity. albeit from a low base. Several govermment programs are focused on additional investments in the top laver of research universities. led by Tsinghua University and Peking University. Between 1996 and 2005 China's investment in R\&D as a proportion of GDP rose from 0.57 to 1.35 per cent (World Bank. 2008) and in the first tive years after 2000 it increased at an annual rate of 18.5 per cent per year. almost three times the rate of growth of R\&D spending at the top of OECD Europe (OLCD. 2007). In 2006 China became the world's number two R\&D nation in aggregate. passing Japan. Both commercial research and basic research are growing rapidly. Between 2004 and 2005 international patents filed in China rose by 47 per cent (Li et al. 2008. p. 43). Between 1995 and 2005 the annual number of seientitic papers produced in China rose from 9061 to 41,596 : and China"s annual output of papers rose by 16.5 per cent per amnum (National Science Board. 2008). These are extruordinary growth figures that indicate a remarkable concentration of policy effort.

Where does the Shanghai Jiao Tong University exercise fit into this picture? The global comparisons of university researeh performance collected by the Institute of Higher Education at Shanghai Jiao Tong University were launehed as a nationally. supported project designed to show China exactly where its research-intensive universities were at and to guide investments in the universities. The ranking system was not designed to lavour Chinese universities and build global reputation on an artificial basis. The intention was to monitor the gap in research performance between China and universities in North America, the UK and Western Europe. according to an international benchmark that was based on the American model of the comprehensive research-intensive science university. This was seen as the global standard, the mark of the world leading knowledge-led economy that China wanted to be. It was therefore vital from the start to conduct the comparative exercise as precisely as possible. The Jiao Tong group argued then and continues to state that the only data sufficiently reliable for ranking purposes are broadly available and internationally comparable data of measurable research performance (Liu \& Cheng, 2005. p. 133.) This is measured using a composite index with weights given to the different criteria. The index is primarily driven by academic publication and citation. mostly in science-based disciplines with some attention to social sciences and humanities: 20 per cent citation in leading journals as listed by publisher Thomson: 20 per cent articles in Science and Nature: and 20 per cent the number of Thomson/ISI "HiCi" researchers in the top 250.300 in their fields on the 
basis of citation (Institute for Scientific Information, ISI-Thomson, 2008). Another 30 per cent is determined by Nobel Prizes in the sciences and economics and Fields Medals in mahcmatics. based on their training ( 10 per cent) and current employment (20 per cent). The other 10 per cent is determined by dividing the above total by the number of academic staff (SJTLIHE, 2008). The Nobel indicators are controversial. as the prizes are submission based and, arguably, factors other than merit enter into the decisions.

There is a long lead time between R\&D investment and its manifestation in research outputs. and a further lag in the Jiao Tong indicators themselves, which pick up citations over the previous decade. Nevertheless trends in the Jiao Tong indicate that China's universities have been steadily lifting their research performance according to the self-imposed rankings benchmark. In the first five Jiao Tong rankings, the number of universitics from (hina and Hong Kong in the world's top 500 rose from $\mathrm{I} 3$ in 2003. to 18 in 2008 . Shanghai Jiao Tong University itself moved from the world's top 450 research universities in 2003 to the top 300 research universities in 2008 . There is still far to go to achieve the ultimate objectives. As yet there are no universities from China in the world's top 100 research institutions. The 2008 rankings by discipline found that China had only ten universities with top 100 disciplines. compared to 308 in the USA. 50 in the UK, 26 in Canada and 20 in Germany. However there were nine Engineering schools in China in this category, scond highest level in the world after 49 such schools in the United States (SJTLIHE. 2008). The long climb to parity with the USA has begun and the Jiao long rankings will measure each height as it is reached. Other national governments are also using the liao Tong to drive improvements in research performance.

\section{The Times thigher Retnking}

The annual Times Higher Education Supplement ranking is a different story. Rupert Murdoch's Times decided that a handful of social scientists and ex engineers at China's ninth ranked university were not going to set the frame of the world market and. just over one year after the first Jiao Tong ranking was issued, they produced a very different global ranking. one closer to the methodology of the US News and World Report than that of the Jiao Tong. Like US News, the ultimate purpose was to sell newsmagazines and the focus was on factors that might drive student choice-making between institutions. A secondary purpose might be inferred from the outcome of the exercise, which was to elevate the global position of British universities, or at least to elevate criteria for comparison and methodologies of comparison which benefited those institutions.

The Times Higher ranking has undergone a long succession of changes in data collection and compilation but the broad approach has remained consistent. Like Shanghai Jian Tong University. it uses a composite index. Unlike the Jiao Tong, it captures a broader group of phenomena than those solely related to research. Half the index is grounded in reputation, 40 per cent comprised by a survey of academics ("peer review') and 10 per cent by a survey of 'global employers". There are two internationalisation indicators: the proportion of students who are international 
( 5 per cent) and the proportion of stalt ( 5 per cent). Another 20 per cent is fixed by the student-staff ratio, a quantity measure intended as proxy for teaching "quality". The other 20 per cent is comprised by research citation performance per academic staff. The Times issues an annual list of the top 200 universities in order, plus rankings by institution in natural sciences, engineering and $\mathrm{TT}$. biomedicine. social science and arts/humanities (Times Higher. 2008).

Like the Jiao Tong rankings, the annual Times Higher rankings are widely publicised each year and sucessful universities nake much use of the rankings position in their marketing campaigns. But the process of data collection. which is handled by a marketing company that uses market research techniques that do not pass social science tests, is less rigorous than at Shanghai Jiao Tong University. For example in 2006 the survey of academic "peers" gathered a response of just I per cent from 200,000 e-mails sent worldwide. The pool of responses was weighted towards the UK and former countries of the British Empire where The limes was well known. such as Australia. New Zealand. Hong Kong. Singapore and Malaysia. Rates of return from Europe and the USA were significantly lower. The returns were not re-weighted to correct for this compositional bias. There are other problems with the Times Higher approach. Arguably, teaching quality cannot be assessed using student-staff ratios. Resourcing is one condition of teaching quality but it does not guarantee it. Research is only 20 per cent of the index. which might be appropriate to the global commercial market in degrees, but arguably is not the way that most of the world values best universities". The student internationalisation indicator rewards an institution for student volume without accounting for the quality or quantity of applications. It focuses on the capacity to generate global revenue as an end in itself rather than best university' global quality. Again. this makes sense in commercial terms. The Times Higher ranking rewards a university's marketing division better than its researchers.

The outcome is a conglomerate league table. It elevates the stellar universities in the USA and UK via the reputational and rescarch indicators. It picks up the best known institutions in national systems especially those located in national capitals. via the reputation indicators. Thus the leading (hinese universities do better in the Times Higher than the Jiao Tong. The reputational indicators and internationalisation indicators are also affected by the intensive cross-border marketing of some Australian and UK universities. The result is a less coherent order in which the hierarchy of research universities is under-determined by the hierarchy of universities providing mass education in the commercial cross-border market. Below the top 40 places the Times Higher ranking has also proven to be highly volatile. Institutions undergo sharp rises and/or falls and a university markets itself on the basis of its Times ranking at peril because the position can suddenly decline. The University of Malaya in Malaysia dropped from rank 89 in 2004, to 169 the following year and then out of the rankings altogether. The Vice-Chancellor's contract was not renewed. From 2004 to 2006 the University of Geneva in Switzerland moved from outside the top 200 to 39 . Fudan University in China was ranked at 195.72 and 116 in successive years, the University of Scoul in Korea jumped from 118 to 63 . RMIT University in Australia dropped from 55 to 146 (Times Hligher. 2008). 
These huge fluctuations are not performance related. They are principally random effects triggered by weaknesses in data gathering and changes in data collation methods. Over time this has tended to undermine the credibility of the rankings.

The Times Higher ranking also generates less random effects that are integral to the political econony of the exercise. Reflecting the composition bias in the peer survey and the focus of the indicators on factors germane to the global market in degrees. the U $K$ and Australian institutions perform rather too well. The UK has just 15 per cent of the GDP of the USA but the UK has almost half as many universities as the USA in the Times top 100 in 2006: UK 15. USA 33. Thus the Times manages to reduce American global dominance from 54 research universities in the Jiao Tong ranking to just 33 in its own league table. The individual positions of the British universities are higher also. In 2006 the UK had two of the Times Higher top three and Cambridge $U K$ had almost closed the gap on llarvard. Yet the Harvard faculty is cited at three and a half times the rate of Cambridge and has far greater world-wide prestige. Further. Australian universities tend to perform exceptionally well in the peer survey of academic staft, and in the student internationalisation indicator. In 2006 the Australian National University was ranked by the Times 'academic peers" ahead of Yale. Princeton, Caltech, Chicago, U Penn and UCI.A. Despite a relatively poor citation rate and moderate staffing ratios. Australia had 13 of the Times top 200 universities, making it the third strongest national system. ahead of Japan. Canada, Germany and France. This makes sense in relation to the global degree market but not total performance or global university standing.

\section{The CHE Compariwons in Gimam}

The Centre for Higher Education Development (CHE). located in Gutersloh in North Rhine-Westphalia in Germany, has moved in the opposite direction. It has turned its back on the pervasive idea of higher education as a marketplace of competing firms. The CHE comparisons are produced in conjunction with the German Academic Exchange Service and the publisher Die Zcit and have now been replicated in other European nations. They do not use reputation-sensitive whole-of-institution league tables. and focus on the generation of comparative data that will he of maximum usefulness to choice-making students.

CHE surveys 1.30 .000 students and 16.000 staff in almost 250 institutions. collecting data on student experiences and satisfaction. and academic recommendations on the best locations in each field. It focuses on 36 academic subjects each offered by a substantial number of institutions. It supplements the surveys with independent sources comprising one third of the data base. No data are taken from institutions. CHE ranks departments according to each separate indicator of academic and service quality, assigning them to top third. middle third or bottom third of all institutions. It refuses to integrate the indicators into a single weighted indicator either for each subject or each institution. It states that there is no one best university" across all areas. and 'minimal differences produced by random fluctuations may be misinterpreted as real diflerences" (CILE. 2006). CHE notes 
also that students have heterogeneous preferences as to mission and purpose. Accordingly, the CHE data are made avallable to prospective students and the public free of charge via an interactive web-enabled database. Any person can interrogate this data base by investigating the comparisons in their own chosen disciplines and services, thercby creating the weightings and rankings themselves.

By dispensing with holistic rank ordering of institutions in league tables, the CHE avoids problems of arbitrary weighting and composite indicators and admits multiple purposes into the comparison. It has partly shifted the nomative power of the comparison process from the ranking agency to the user of higher education. The approach lacks the discursive potency and economic lock-in of a single league table: but arguably the data are more informative to more people. In Europe the approach has proven attractive to public and students. govermments. and academic experts on rankings systems (van Dyke. 2005: Salmi \& Saroyan. 2006: I sher \& Savino, 2006). The CHE data collection has been extended to Switzerland. Austria. the Netherlands and Flanders, the Dutch-speaking portion of Belgium. "The Clll: ranking system is thus well positioned to develop into a luropean-wide system (Van der Wende. 2007). It is a significant counter-weight to those university ranking systems that constitute higher education as a market of competing institutions but is unlikely to displace them altogether.

\section{Ramkings and Conat-Determination}

Once through the door. the logic of conpetition is relentless. The driving imperative imposed by global university rankings is to lift performance measured in normreferenced terms within this global frame of reference. Inereasingly, this imperative is governing the behaviour of those with overarching responsibilities for institutions (university presidents, rectors and vice-chancellors) and national systems (ministers and officials). Ministers redouble the pressure on university leaders. Every govermment would like to lift its nation's capacity to compete in what is now universally imagined as the global knowledge economy. Here university rankings provide one of the few simple clear-cut indicators of the nation"s competitive position.

Ellen Hazekorn reports on a survey of higher education leaders and managers in 41 countries, concerning the impact of league tables and ranking systems. She finds there is widespread concen about rankings and also a readiness to respond to them. Hazelkorn's survey finds that 58 per cent of university leaders are unlapps with their current institutional rank. 93 per cent want to lift their national position. 82 per cent want to lift their global position and 71 per cent want to be in the global top quartile. Almost universally. respondents testified that rankings are a critical factor underpinning and informing institutional reputation' and a crucial factor in determining student applications. though there are varied opinions on how crucial it is (Hazelkorn, 2008; quotes here and helow from her article. pp. 197201 , derive from interviews). It is considered more important for international students than for local students who often utilise other sources of information. Rankings are seen as equally crucial in influencing government support and funding. and in shaping the pattern of international university partnerships. Rankings are also widely used by 
employers in recruiting graduates and by universities themselves in recruiting academic staff. More than 56 per cent of Hazelkorn's respondents said that their institution had established a formal mechanism to review its ranking position and consider ways and means of improving it: and 63 per cent state they have taken strategic. organisational. managerial or academic actions. Only 8 per cent of respondents stated that they had taken no action in relation to rankings.

Institutional leaders confirm they take rankings seriously, embedding them within their strategic planning processes at all levels of the organisation, including Governing Authority. Senior Executive and School/College. Depending upon the institutional strategic objective vis-à-vis their current position. HEls (higher education institutions) use ranking metrics to guide their own goals. This may mean setting student and faculty recruitment targets (e.g. specifying academic entry criteria, making conditions of appointmentpromotion clearer and more transparent, appointing Nobel prize winners). indicating individual academic performance measurements (e.g. research activity and peer-review publications, programme development). setting school/college level targets, and/or contimual benelmarking exercises. As one respondent stated: "the improvement of the results has become a target in the contract between presidency and departments', while another confirmed they have "developed a set of internal research output indicators... we do internal benchmarking".

Some HEls have restructured departments, invested in their organisation's facilities or improved awareness and expertise in the Research and Innovation Office". Many HEls have established an institutional research office to collect data. monitor their performance. better present their own data in public or other official realms, and benchmark their peers' performance. Others have taken a more aggressive approach. using rankings as a tool to influence not just organisational change but influence institutional priorities. In this respect, both teaching programmes and research are mentioned. Respondents spoke of using ranking 'to drive activities at university, faculty and campus levels" and 'for internal budgeting".

Rankings function as the meta-performance indicator. The criteria used to determine the order of rank become meta-outputs that each institution is recuured to place on priority so that rankings begin to define "quality". In the world of the Jiao Tong rankings. "quality" means scientific research and Nobel Prizes rather than teaching or community building or solving local or global problems. According to the Times Higher "quality" menns reputation, larger staff-student ratios, research. and international staff and students: and it is partly fostered by marketing. By shaping university and system behaviours and standardising the definitions of outputs. all the way down from the governing council/senate to the classroom and the research laboratory, ranking systems begin to shape university mission and the balance of activity, externalising part of university identity. This shift from autonomy to heteronomy carries with it scrious problems for the trajectory of higher education in many countries, robbing not only institutions but national systems of part of their control over their identity and creating savage pressures to homogenise according to the model of an English-speaking science heavy university. This excludes from status or weakens the status of not only institutions focused on shorter course 
vocational education but most technical universities: non-comprehensive specialist institutions in medicine, engineering. business and the arts, and institutions combining a very broad range of functions and missions. so that research is a relatively small part of their contribution to the national system. such as the leading national universities in Mexico and Argentina.

At the same time the loss of autonomy is not universal. We should be wary of claims that the sector ax a whole is shackled by the abstract forces of marketisation or global norming. Rankings-driven heteronomy scarcely touches institutions at the very top whose intemal life is reflected in the templates of the rankings systems. which remain masters of their identity, and who now take their place at the head of the global knowledge economy along with Google and Microsoft. It is true that rankings technology imposes on the traditional elite a regine of greater transparencs in which performance is more harried. It breaks down some of the gothic mystery of the leaders, the ineffable essence inherited from their clerical origins from which they used to draw much of their authority. Nevertheless they have become more powerful overall. In the era of global rankings. the Ivy League. Cambridge and Oxford cut stronger figures in the world, amid a more vertically differentiated network of universities in which the number of elite universities has shrunk. On the other hand, outside the USA and UK, the status of elite institutions at the national level is partly displaced by the global super-league at the top of the tables. and major public or national universities are lacing downward pressures in the us as elsewhere (Calhoun, 2006).

Since the Jiao Tong began in 2003, rankings have strengthened support in government for increased investment in university research and the concentration of research resources in leading universities. sometimes at the expense of other institutions and sometimes not, in order to lift the rankings position. China"s policy has already been mentioned. Germany is investing 1.9 billion euros in the Exzellenzinitiative program. initially in three universities, and this may foreshadow a regeneration of German global capacity in university research. The European Commission has established a target of R\&D investment of 3 per cent of GDP across all member countries and plans to establish a collaborative super-institution. the European Institute of Techology. Other nations will follow. more so if China's transition to a research-intensive economy is successful. This offers universities the prospect of larger research budgets, and also intensified controls as governments seck to secure tangible results from their investment. For the world it means an "arms race" in investment in innovation. an ever-growing reliance on the use of rankings, and more precisely targeted rankings technologies.

\section{Ramkings and Gowernamere}

Of all the new faetors that have emerged in the last decade, global university rankings have had a greater impact on higher education and especially research policy than any other. with the possible exception of II September 2001 and the IS response. For example, rankings have had a greater shaping effect in the strategies and priorities of higher education than the mainstraming of concerns about climate change 
following the $(k$ Stern report. This is remarkable and it raises the analytical and political stakes in questions of interpretation. That is a longer discussion than there is room for in this chapter. which will be conlined to a small number of points about rankings and governance. (There is further discussion elsewhere: see, for example. Marginson \& van der Wende, 2009b; Marginson. 2007b; Marginson. 2007c).

First. it would be misleading to see rankings as imposed on higher education institutions in each country from outside the sector. by government or business or by the endogenous forces of global economic competition. It is true that all of these elements are in play. But global rankings are distinct from other technologies of performance monitoring and management characteristic of the New Public Management in the neo-liberal era. They did not originate in the systems of control and micro-management used by state agencies or large corporate bureaucracies operating at the national level. They are an explicitly global technology, their function is the ordering of global relations in higher education where there is no state or policy regime. and even their one national-system genesis in the US News exercise was outside government. Notwithstanding the role of the Chinese government in supporting the genesis of the Jiao Tong rankings, rankings sprang largely from civil society and higher education itself and were widely and popularly cmbraced before their endorsement and use by governments and university managers as tools of surveillance and incentive-making.

As this chapter has demonstrated, global university rankings were developed by two groups of agencies operating outside the sphere of government and organisation: first, publishing companies such as US News and The Times; and second, academic units like the Jiao Tong Institute and the CHE, competent in sociological research. These two sets of agencies have different purposes and techniques. Their ranking systems diverge. But they share a capacity to imagine and vector wide-ranging common spaces and thus to construct a global dimension of higher education. In turn this global imaginary has locked onto the signs of global convergence that we observe more or less continuously: the accelerating flows of students, academic persomel. messages, ideas, research data, policies. organisational templates, technologies and momey; all of which helps us to visualise global higher education as a single environment and renders more credible the idea of a global league table (gross over-simplification though it is) (Marginson \& van der Wende, 2007b). More tendentiously. rankings imagine that global environment as a market of competing institutions. This also connects to what many people already know. It fits with the familiar neo-liberal conception of education as an economic market and the Anglo-American notion of globalisation as the roll out of world-wide markets. The notion of the global market gains salience from the actual commercial competition for international students, the competitive element in research, and the long-standing status hierarchy among traditional universities. Hazelkorn concludes that it is clear that rankings are a manifestation of the already competitive global market in which higher education operates, and are being used and perceived as such (Hazelkorn, 2008, p. 211). That is too neat. It downplays the role of cross-horder collaboration and especially free knowledge flows. The global public goods produced in higher education are much more significant than the global private goods 
(Marginson, 2007a). But Hazelkorn is right about the conditions of emergence. The notion of universities as teams in a knowledge cconomy World cup is not the only way to imagine the global dimension of higher education. But it fits with the policy times and has grabbed the imaginative space.

Second, notwithstanding their origins, university rankings quickly achieved a productive symbiosis with the New Public Management and neo-liberal political economy in higher education, in almost every nation. (Global rankings have little impact in the USA where the national market is seen to embody the best institutions in the world: the US News still reigns). As the meta-performance indicator, rankings strengthen the hand of government in imposing on institutions a performance culture and a regime of measured outcomes, and strengthen the hand of managers in mimetically imposing these systems on academic units. as Hazelkom's study indicates. No doubt neo-liberal governance provides favourable conditions for ranking and ensures that the outcomes of such comparisons will be instantly noticed. At the same time institutional ranking reinstalls as ideology key elements of neo-liberal governance. It explicitly orders higher education as a global market of competing teams (quasi-firms), and shifts the onus of responsibility for improving the quantity and quality of research and higher education from governments to institutions and so on down the chain. As with all systems hased on self-regulation. autonomy is valued and acquiescence is voluntary but the goal power of ranking is compelling. All university league tables, national or global. position university executives and researchers as self-regulating market actors. As vikolas Rose remarks, this is 'the conduct of conduct' in which forms of frecdom become the medium of marketisation. and human agents are players in the ubiquitous competition games (Rose, 1999). Here global university ranking is a form of global governmentality' whereby global systems and factors, even global factors that are invented for the purpose and then take on a life of their own, are used as tools of governance at national and local levels and are selectively chamnelled into the shaping of behaviours (Larner \& Walters, 2004).

Third, the advent of global research rankings take us into a space that is national and post-national at the same time. It is post-national and global in that it arranges the higher education world as a network of equivalent institutions transparent in terms of uniform criteria, like the elements that comprise physical chemistry, without regard for the particular character of each institution and the circumstances goverming its performance. Research rankings are also post-national in the sense that research and knowledge flow cross borders without restraint. Although English is the one common language of research. so that research measurement favours the linglish-speaking systems - a very significant limitation for those working in non Lnglish-speaking countries - in principle the common research conversation is open to all.

At the same time. global rankings are also national because kague tables and rankings performance readily translate into comparison between nations (i.e. an inter-national as well as global comparison), and not just between instiutions qua institutions and between their academic disciplines. Also national investment remains the largest influence on university eapacity to perform. even in the LSA where federal science funding is determining. Global university ranking. like all 
such league tables of comparative international performance, speak to the role of national government at the apex of the "global competition state", which is becoming the principal way of understanding the nation in this era. Except perhaps in the USA, the nation is no longer a horizon unto itself and increasingly is understood in terms of its position and trajectory within the global setting. The adoption of this outlook in China, in place of the old autarky of the Middle Kingdom. largely indifterent to the world beyond its historical borders. is a major shift.

Fourth. global university ranking. and the technologies of output measurement that have become associated with it (publication counts, citation counts, journal rankings. impact measures, methods of securing equivalence across field, and so on). are a system for assigning workable economic values to the products of universities and to universities as institutions. Trends in a university"s rank can be seen as equivalent to the rise and fall of corporate equity prices, where the issue is not the absolute level of the price but its trajectory, up or down. The number of a university"s publications. reworked according to an index of quality, can be seen as a precise indicator of the research it produced in the preceding period. Once credible calculations are installed the numbers take on great weight (consider the power of the US News despite widespread critique of several of the measures). Exact funding can be allocated on the basis of rankings metrics. by govermments, business firms and philanthropists. In other words the notion of universitics as competing units of production has the potential to become more than an ideology shaping behaviour; it could become an operational economic system. University research in rankings systems still falls short of the capitalist ideal. Free scientific production placed in the public domain has no prices attached to it. and it is difticult or impossible to ascribe monetary value to the indirect benefits that research knowledge creates in the production process in industry. Nevertheless, the research ranking technologies constitute a significant step in the direction of the economisation of higher education. At the least, rankings have laid the basis for one form of precise targeting of govermment investment and for the ever intensifying micro-management of free public knowledge goods.

Finally. global university ranking constitutes an attempt to order the worldwide higher education environment in particular ways. On the vast open possibilities conjured up by global communicability and cultural flows (Marginson. 2008), it imposes an audacious closure. one that clearly assists some interesis and not others. Ranking strengthens and reproduces the domination of the English language university systems. It installs the model of the top American research university (more particularly the idealised private university, the Ivy League) as the dominant template for higher education on a worldwide basis, even though no other nation has the global power or resources to imitate this kind of institution. It encourages the centralisation of research activity in fewer. stronger institutions and so directs imnovation and the knowledge economy down restricted pathways. As discussed. by relegating all but the leading science universities to a subordinate position, it sharply bears down on diversity within and between nations. Because there is only one valued mission. this narrows the seope for upward institutional mobility and especially for mould-breaking organisational designs. There is some space for the 
upward mobility of institutions and systems. The govermments of China, Singapore. Korea and Tawan China are particularly interested in global ranking because this technology enables them to track the progress of their own institutions. The challengers of hegemony on the grounds of hegemony. these systems will face continuing tensions in national strategy between cultural identity and the processes of global modernisation.

Global university ranking is here to stay. Responding political strategics will have to work around it. alongside it. under it and over the top of it. Ranking as such will not disappear. Global league tables cannot altogether block the potential for other kinds of cross-border relations and for forms of high quality institution other than the research-intensive English language university. But they pose the need to factor back in diversity (of institutional types, of languages. of knowledge. of modes of governance) and the non-competitive global exchange of people and knowledge. A key move is to pluralise comparison itself, to move part of the action away from the whole of institution league tables that recycle inherited reputation and resources and so preserve the global and national status quos. The CHE"s interactive data for student choice are one example of such pluralisation. The more numcrous and varied the means of comparison on offer, the better informed we will be and the less that any one system of comparison can secure enough weight to shape global relations decisively in its own image.

\section{NOTES}

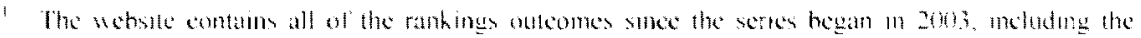

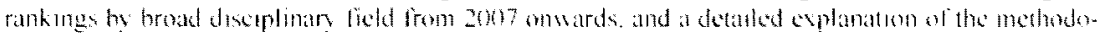

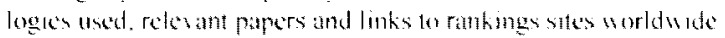

\section{RIIITRINCIS}

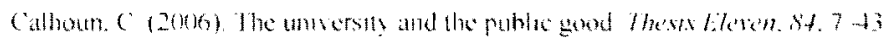

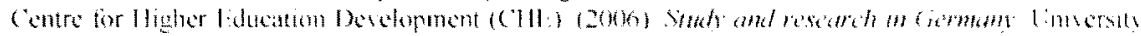

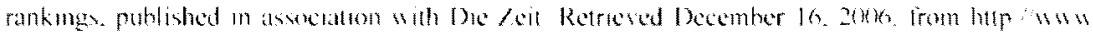

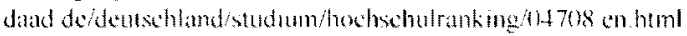

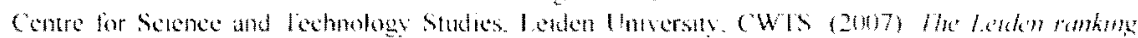

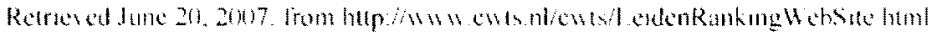

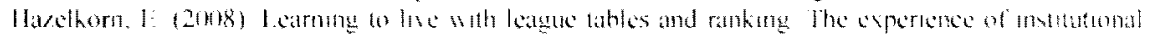

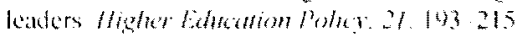

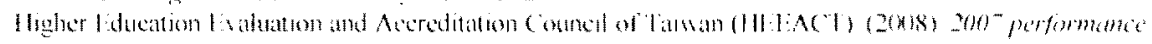

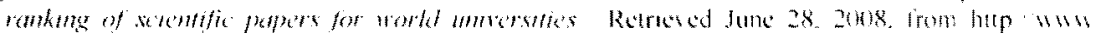

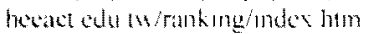

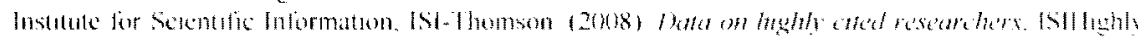

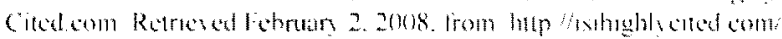

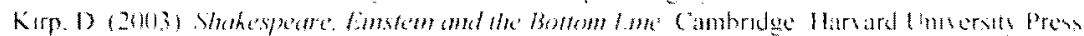

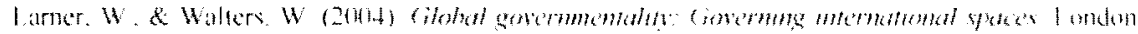
Routledge

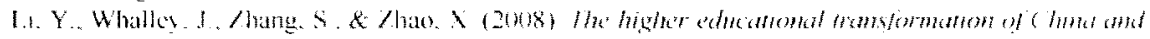

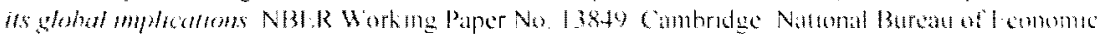
Reserth

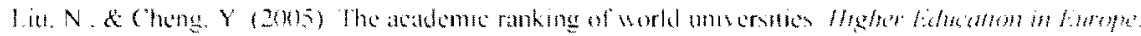
$312.127-136$ 


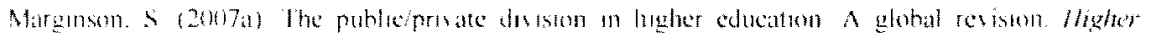
lidkathom. 53,317733

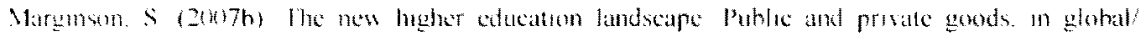

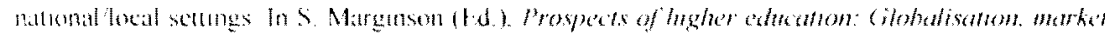

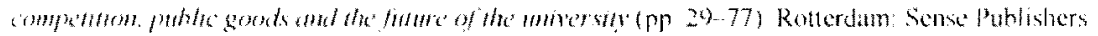

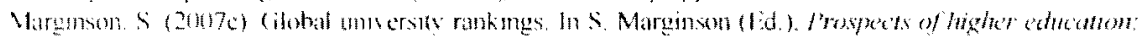

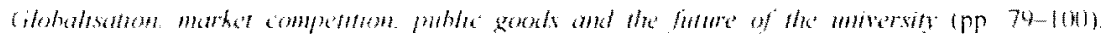

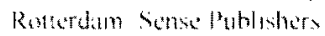

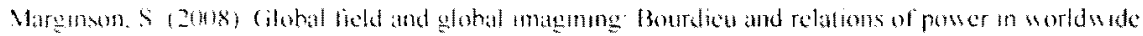

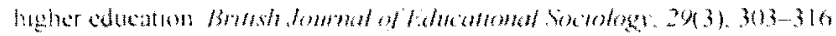

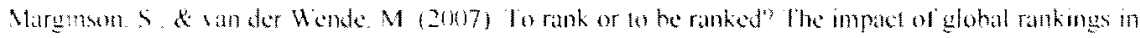

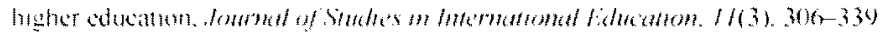

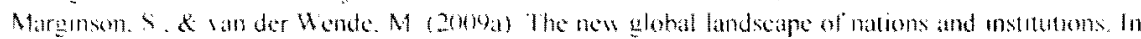

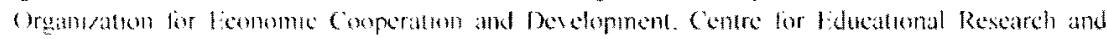

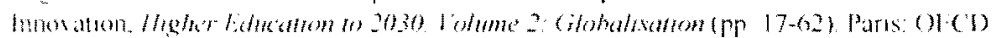

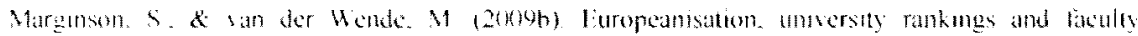

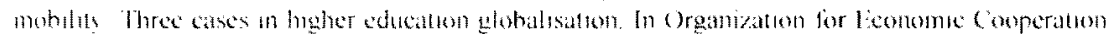

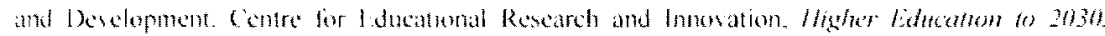

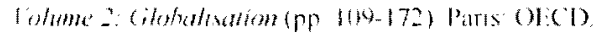

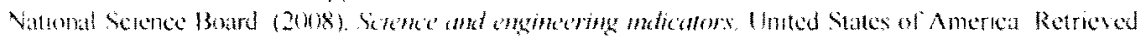

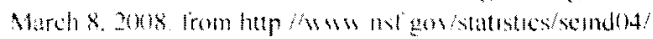

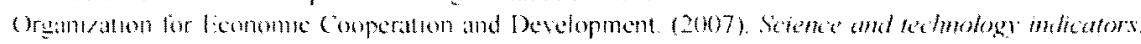
Pials (I)

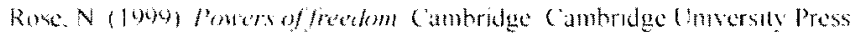

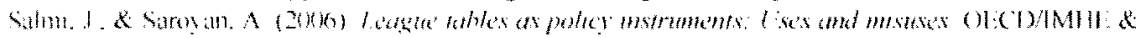

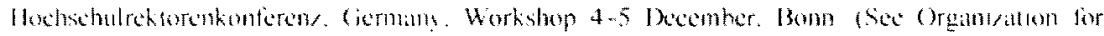

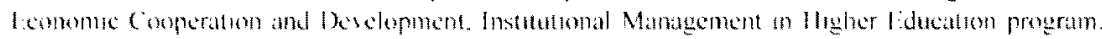

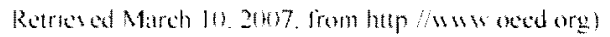

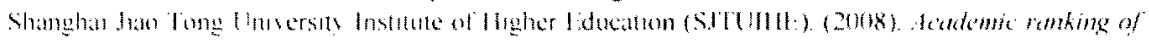

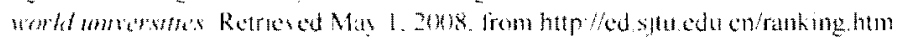

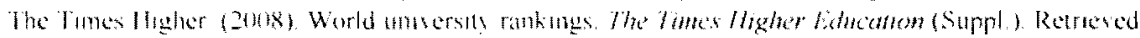

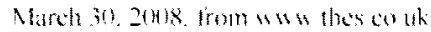

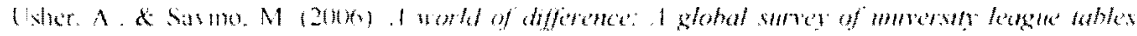

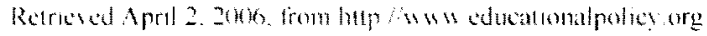

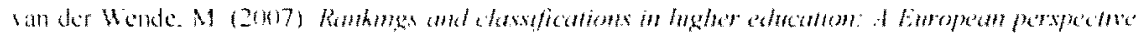

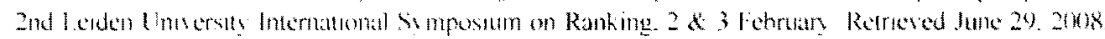

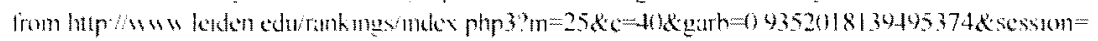

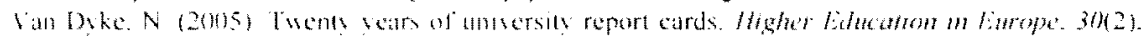
10,125

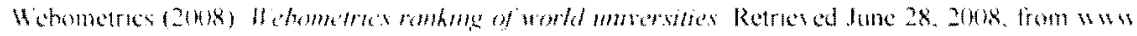
sebometrics mis:

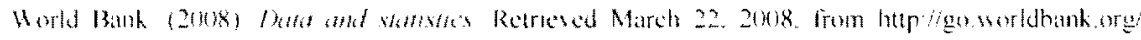
$47 ?: 31940$

\section{Simm Marginwom}

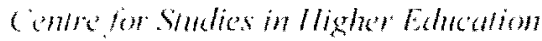

(niversily of $M$ ol

\section{Welhoume}

fustralia 


\section{University Library}

\section{- M M I N E R VA A gateway to Melbourne's research publications}

Minerva Access is the Institutional Repository of The University of Melbourne

Author/s:

Marginson, SWM

Title:

How Universities Have Been Positioned as Teams in a Knowledge Economy World Cup

Date:

2010

Citation:

Marginson, S. W. M. (2010). How Universities Have Been Positioned as Teams in a Knowledge Economy World Cup. Blackmore, J (Ed.). Brennan, M (Ed.). Zipin, L (Ed.). RePositioning University Governance and Academic Work, (1), pp.17-33. Sense Publishers.

Persistent Link:

http://hdl.handle.net/11343/30618 